\title{
Faunal diversity of rotifers (Rotifera: Eurotatoria) of Nokrek Biosphere Reserve, Meghalaya, India
}

\author{
B.K. Sharma ${ }^{1} \&$ Sumita Sharma ${ }^{2}$ \\ ${ }^{1}$ Freshwater Biology Laboratory, Department of Zoology, North-Eastern Hill University, Permanent Campus, Shillong, Meghalaya \\ 793022, India \\ ${ }^{2}$ North Eastern Regional Centre, Zoological Survey of India, Risa Colony, Fruit Gardens, Shillong, Meghalaya 793003, India \\ Email: ${ }^{1}$ profbksharma@gmail.com (corresponding author), ${ }^{2}$ sumitasharma.nehu@gmail.com
}

\begin{abstract}
Plankton samples collected from the Nokrek Biosphere Reserve of Meghalaya (Northeast India) revealed 70 species of Rotifera belonging to 24 genera and 15 families. Eight species are new records from the state of Meghalaya. The Oriental Lecane blachei and the palaeotropical $L$. unguitata are biogeographically interesting elements. The Rotifera taxocoenosis of Nokrek Biosphere Reserve is characterized by a distinct richness of the 'tropic-centered' genus Lecane, paucity of Brachionus species, greater diversity of littoral-periphytonic elements and a genera 'tropical' character with cosmopolitan $(71.4 \%)>$ tropicopolitan $(17.1 \%)$ species.
\end{abstract}

Keywords: Faunal diversity, India, Nokrek Biosphere Reserve, Rotifera.

Rotifera or 'Rotatoria' comprise an important group of freshwater invertebrate as well as an integral component of aquatic food-webs. Taxonomic studies on Rotifera from India began more than one century ago (review by Sharma 1998a). Sharma \& Sharma

\author{
Date of publication (online): 26 February 2011 \\ Date of publication (print): 26 February 2011 \\ ISSN 0974-7907 (online) | 0974-7893 (print) \\ Editor: Hendrik Segers

\section{Manuscript details:} \\ Ms \# 02527 \\ Received 26 July 2010 \\ Final received 15 December 2010 \\ Finally accepted 28 December 2010
}

Citation: Sharma, B.K. \& S. Sharma (2011). Faunal diversity of rotifers (Rotifera: Eurotatoria) of Nokrek Biosphere Reserve, Meghalaya, India. Journal of Threatened Taxa 3(2): 1535-1541.

Copyright: (c) B.K. Sharma \& Sumita Sharma 2011. Creative Commons Attribution 3.0 Unported License. JoTT allows unrestricted use of this article in any medium for non-profit purposes, reproduction and distribution by providing adequate credit to the authors and the source of publication.

Acknowledgements: This study is undertaken under the "University with Potential for Excellence Program (Focused Area: Biosciences)" of NorthEastern Hill University, Shillong. Thanks are due to the Head, Department of Zoology, North-Eastern Hill University, Shillong for laboratory facilities. One of the authors (SS) is also thankful to the Director, Zoological Survey of India and the Officer-in-charge, North Eastern Regional Centre, Zoological Survey of India, Shillong. Finally, the permission granted by the Conservator of Forests, Meghalaya is sincerely acknowledged. The authors are thankful to one reviewer for valuable suggestions.

\section{OPEN ACCESS | FREE DOWNLOAD (c) (1) (1)}

(2005a, 2008) analyzed the progress in studies in the northeastern India region. The Indian literature shows a paucity of works on the faunal diversity of phylum Rotifera from aquatic biotopes of conservation areas of India in particular. The relevant works from northeastern India are limited to studies from the Pobitra Wildlife Sanctuary of Assam (Sharma 2006) and two Ramsar sites, namely Deepor Beel (Sharma \& Sharma 2005b) and Loktak Lake (Sharma 2009). On the other hand, Rotifera inhabiting water bodies of various biosphere reserves of this region are yet to be examined. The present study on the faunal diversity of rotifers of the Nokrek Biosphere Reserve Meghalaya, hence, assumes special importance in view of the stated lacunae. Various species examined from this biodiversity hotspot are listed. Comments are made on the nature and composition of the rotifer fauna and on the distribution of interesting species.

\section{Materials and Methods}

Study site: The Nokrek Biosphere Reserve (25020'$25^{\circ} 29^{\prime} \mathrm{N} \& 9^{\circ} 13^{\prime}-90^{0} 35^{\prime} \mathrm{E}$ ) spreads (Fig. 1) over parts of West, East and South Garo Hills districts of the state of Meghalaya. It was declared as a national park in 1997 $\left(47.48 \mathrm{~km}^{2}\right)$ and was designated as biosphere reserve $\left(82.0 \mathrm{~km}^{2}\right)$ in May 2009 . It abounds in various wildlife including elephants, Western Hoolock Gibbon, rare varieties of birds and pheasants, beside rare orchids. It is also a national citrus gene sanctuary to a very rare endemic species of Citrus indica which the locals call memang narang ('orange of the spirits').

Methods of study: One-hundred-and-ten plankton samples were collected from different water bodies of the Nokrek Biosphere Reserve in July and September 2009, and January 2010, with a nylobolt plankton net (mesh $25 \mu \mathrm{m}$ ) and were preserved in 5\% formalin. All the samples were screened with a Wild 


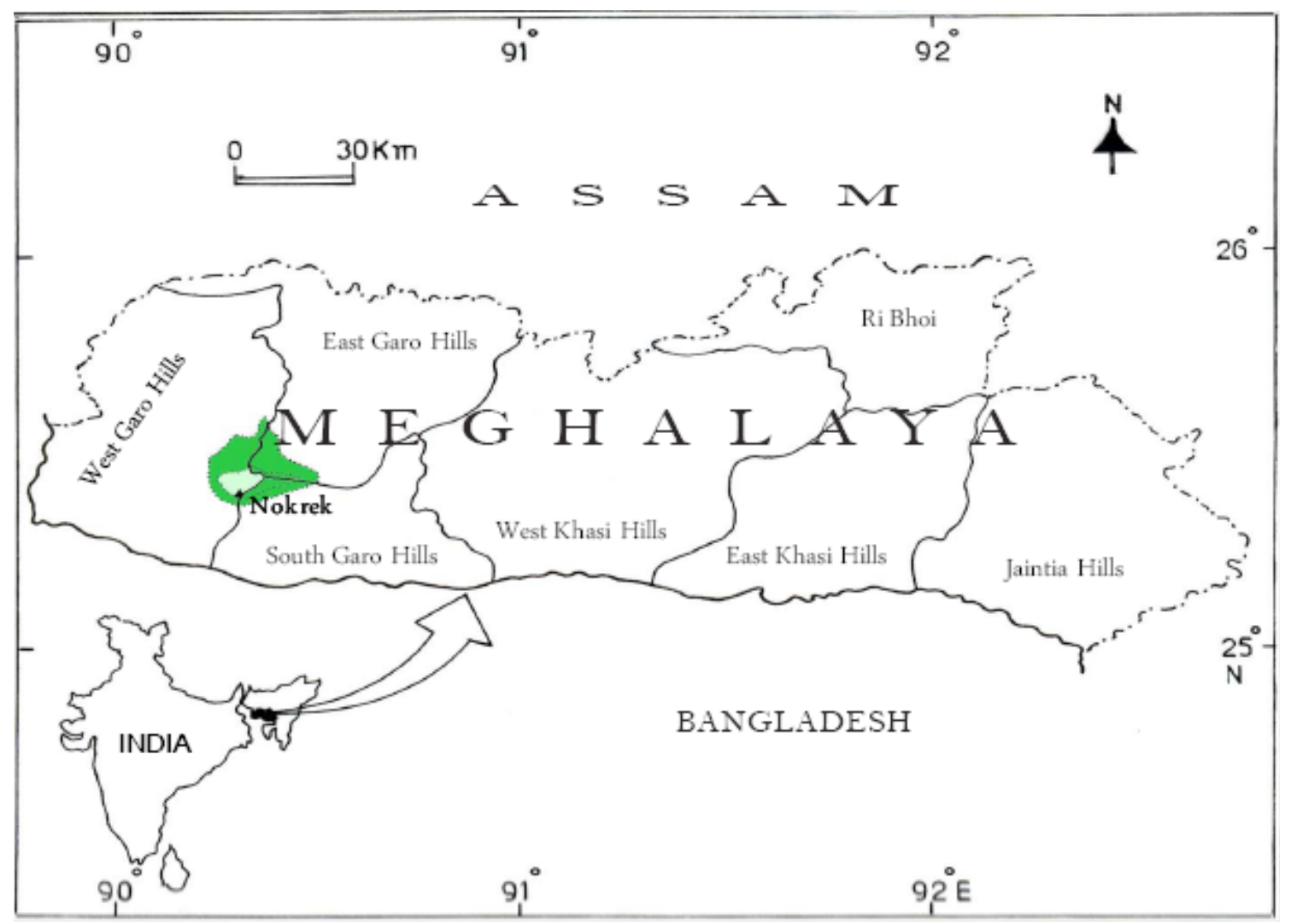

Figure 1. District map of Meghalaya showing location of Nokrek (inset map of India showing locationof Meghalaya State)

stereoscopic binocular microscope and the rotifer taxa were isolated. Permanent slides of different species mounted in Polyvinyl-alcohol lactophenol mixture and deposited in the holdings of the senior author (BKS) were examined with Leica DM 1000 image analyzer. In addition, specimens in the holdings of NERC, ZSI, Shillong were examined by one of the authors (SS). Rotifera species were identified following the works of Koste (1978), Sharma (1998b), Segers (1995), and Sharma \& Sharma (1999, 2000, 2008). The system of classification of the Rotifera followed in this account is after Segers (2002).

\section{Systematic list of the examined species}

Phylum: Rotifera

Class: Eurotatoria

Subclass: Monogononta

Order: Ploima

Family: Brachionidae

1. Anuraeopsis fissa Gosse, 1851

2. A. navicula Rousselet, 1911

3. Brachionus angularis Gosse, 1851

4. B. bidentatus Anderson, 1889

5. B. calyciflorus Pallas, 1766
6. B. falcatus Zacharias, 1898

7. B. mirabilis Daday, 1897 *

8. B. quadridentatus Hermann, 1783

9. Keratella tropica (Apstein, 1907)

10. Platyias quadricornis (Ehrenberg, 1832)

11. Plationus patulus (O.F. Muller, 1786)

P. patulus macracanthus (Daday, 1905)

Euchlanidae

12. Euchlanis dilatata Ehrenberg, 1832

13. Dipleuchlanis propatula (Gosse, 1886)

14. Tripleuchlanis plicata (Levander, 1894)*

15. Beauchampiella eudactylota (Gosse, 1886)

Mytilinidae

16. Lophocharis salpina (Ehrenberg, 1834)

17. Mytilina bisulcata (Lucks, 1912)

18. M. ventralis (Ehrenberg, 1830)

Trichotriidae

19. Trichotria tetractis (Ehrenberg, 1830)

Lepadellidae

20. Colurella obtusa (Gosse, 1886)

21. C. sulcata (Stenroos, 1898)

22. C. uncinata (O.F. Muller, 1773)

23. Lepadella minuta (Weber \& Montet, 1918) 
24. L. ovalis (O.F. Muller, 1786)

25. L. patella (O.F. Muller, 1773)

26. L. rhomboides (Gosse, 1886)

Lecanidae

27. Lecane aculeata (Jakubski, 1912)

28. L. arcula Harring, 1914*

29. L. crepida Harring, 1914

30. L. curvicornis (Murray, 1913)

31. L. haliclysta Harring \& Myers, 1926

32. L. hornemanni (Ehrenberg, 1834)

33. L. inermis (Bryce, 1892)

34. L. leontina (Turner, 1892)

35. L. ludwigii (Eckstein, 1883)

36. L. luna (O.F. Müller, 1776)

37. L. papuana (Murray, 1913)

38. L. nitida (Murray, 1913)

39. L. signifera (Jennings, 1896)

40. L. ungulata (Gosse, 1887)

41. L. blachei Berzins, 1973*

42. L. bulla (Gosse, 1851)

43. L. closterocerca (Schmarda, 1859)

44. L. hamata (Stokes, 1896)

45. L. furcata (Murray, 1913)

46. L. lunaris (Ehrenberg, 1832)

47. L. monostyla (Daday, 1897)

48. L. quadridentata (Ehrenberg, 1830)

49. L. stenroosi (Meissner, 1908)

50. L. unguitata (Fadeev, 1925)

Notommatidae

51. Cephalodella forficula (Ehrenberg, 1830)

52. C. gibba (Ehrenberg, 1830)

53. C. mucronata Myers, 1924

54. Monommata longiseta (O.F. Müller, 1786)

55. M. maculata Harring \& Myers, 1930

Scaridiidae

56. Scaridium longicaudum (O.F. Müller, 1786)

Trichocercidae

57. Trichocerca insignis (Herrick, 1885)

58. T. pusilla (Jennings, 1903)

59. T. similis (Wierzejski, 1893)

Synchaetidae

60. Polyarthra vulgaris Carlin, 1943

Dicranophoridae

61. Dicranophorus forcipatus (O.F. Müller, 1786)

Flosculariaceae

Floscularidae

62. Sinantherina socialis (Linne, 1758)*

63. S. spinosa (Thorpe, 1893)*
Conochilidae

64. Conochilus unicornis Rousselet, 1892

Testudinellidae

65. Testudinella emarginula (Stenroos, 1898)

66. T. parva (Ternetz, 1892)

67. T. patina (Hermann, 1783)

Digononta

Bdelloidea

Philodinidae

68. Philodina citrina Ehrenberg, 1832*

69. Rotaria macroceros (Gosse, 1851)*

70. R. neptunia (Ehrenberg, 1830)

* New records from Meghalaya

\section{Discussion}

This pioneering study on aquatic biodiversity of the Nokrek Biosphere Reserve records 70 species of Rotifera. Eight species namely Brachionus mirabilis, Tripleuchlanis plicata, Lecane arcula, L. blachei, Sinantherina socialis, S. spinosa, Philodina citrina and Rotaria macroceros are new records from the state of Meghalaya. The present report raises the number of rotifer species known from Meghalaya (vide Sharma \& Sharma 1999) to 138 species. In addition, a couple of new species await description. The richness, in turn, comprises $31.7 \%$ of the species known from northeastern India and $50.7 \%$ of the rotifer fauna of the state of Meghalaya. Amongst 22 families and 43 genera of phylum Rotifera recorded from northeastern India (B.K. Sharma unpublished), 15 families and 24 genera are represented in our collections. Although the examined samples reflect a low rotifer diversity of Nokrek Biosphere Reserve, the fauna appears to be fairly speciose when compared with overall rotifer richness known from northeastern India in general and the state of Meghalaya in particular. The documented species, however, present a significant contrast to only 27 species belonging to nine families and 12 genera identified by one of the authors (S. Sharma unpublished) from this biosphere reserve based on limited samples deposited in the holdings of NERC, ZSI, Shillong.

Incomplete Rotifera inventories from the conservation areas of India may not permit meaningful comparisons with our report; this generalization is affirmed by only 14 species reported from the Nilgiri Biosphere Reserve (Patil 2001). The diversity in 
Nokrek Biosphere Reserve is marginally higher than 64 species noticed in summer rotifer communities of 12 floodplain lakes of the Pobitora Wildlife Sanctuary, Assam (Sharma 2006) while it broadly concurs with 74 species examined from some floodplain lakes of Kaziranga National Park (Sharma \& Sharma 2008) of Assam. On the other hand, the richness is distinctly lower than the reports of 110 (Sharma \& Sharma 2005b) and 120 (Sharma 2009) species known from two Ramsar sites of India namely Deepor Beel (Assam) and Loktak Lake (Manipur), respectively as well as the 207 species from floodplain lakes in River Niger Delta, Nigeria, Africa (Segers et al. 1993), 106 taxa from Thale-Noi Lake, a Ramsar site in Thailand, Asia (Segers \& Pholpunthin 1997) and 114 species from the wetlands of the Rio Pilcomayo National Park, Ramsar site of Argentina, South America (Jose de Paggi 2001). However, we caution against overemphasizing the importance of the stated comparisons without considering sampling intensity and the nature of different ecosystems, particularly the floodplains of Assam and Manipur and elsewhere.

Biogeographically interesting elements include the Oriental endemic Lecane blachei (Image 1). This lecanid was described from Cambodia (Berzins 1973) and thereafter recorded from Thailand (Sanoamuang 1998) and India (Sharma 2004) while it is recently

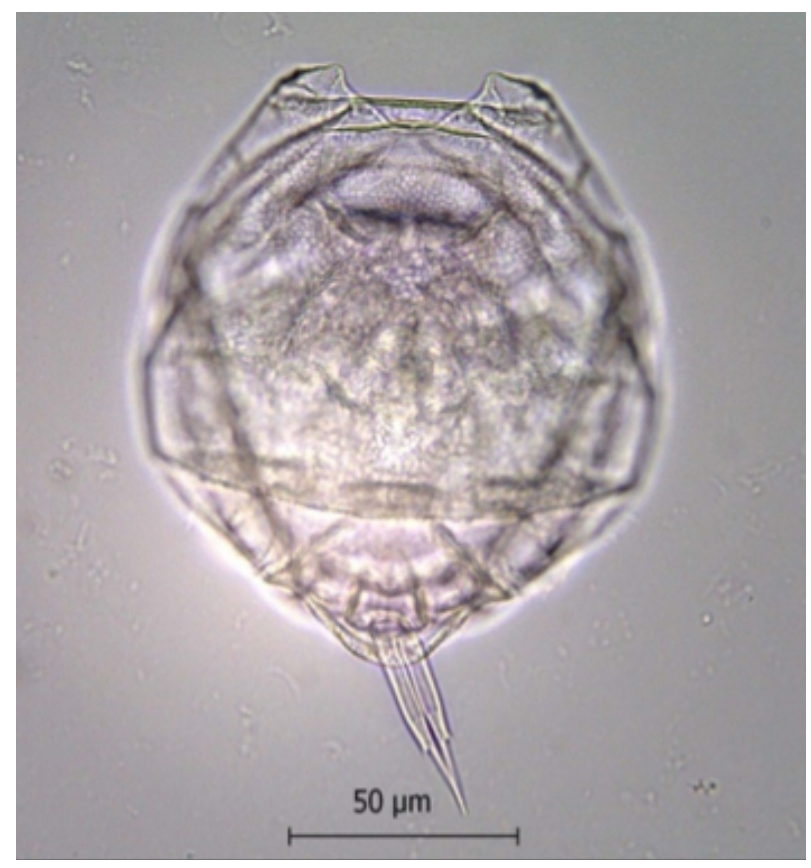

Image 1. Lecane blachei Berzins, dorsal view re-recorded (Seanghun \& Sanoamuang 2010) from Cambodia from the Mekong River basin. $L$. blachei exhibits a disjunct occurrence in India with records from Assam and West Bengal (Sharma \& Sharma 2008). Lecane unguitata (Image 2), another palaeotropical species (Segers 1996) as well as eastern hemispheric element (Savatenalinton \& Segers 2005), shows a relatively wider distribution in India but is rare

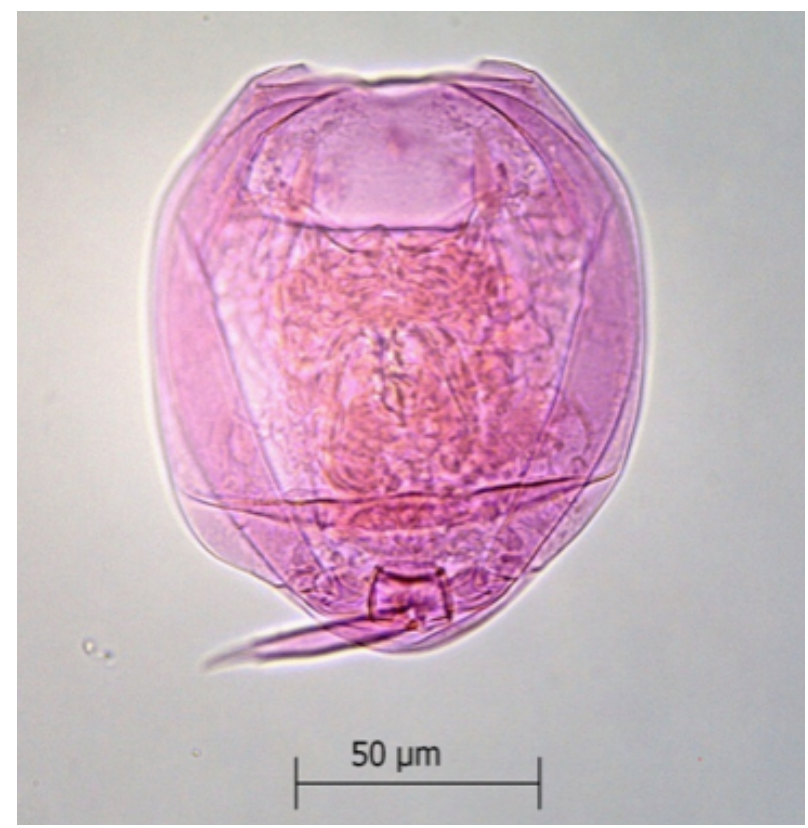

Image 2. Lecane unguitata (Fadeev), ventral view

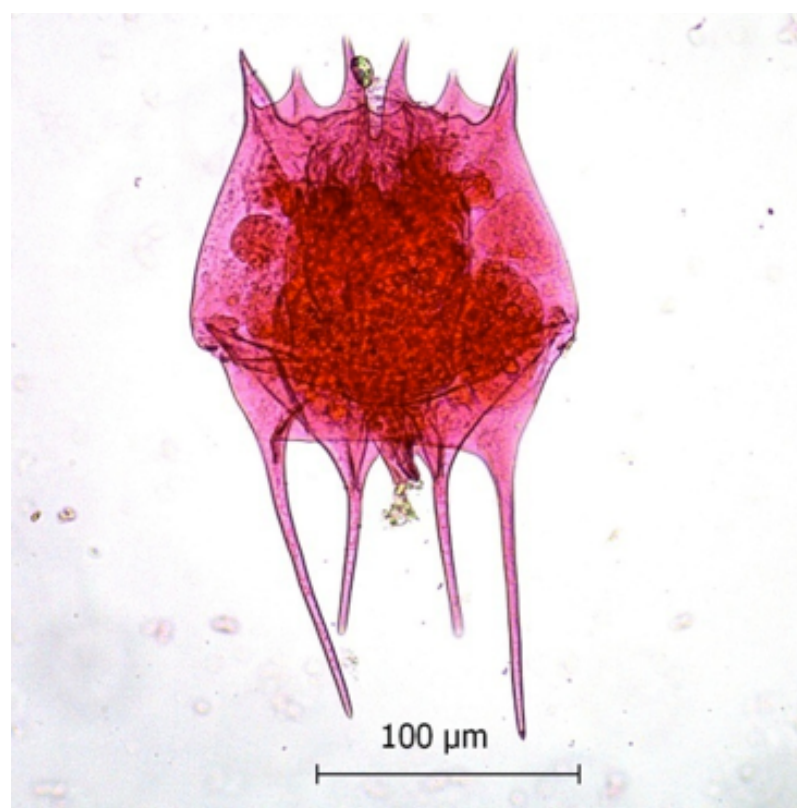

Image 3. Brachionus mirabilis Daday, ventral view 


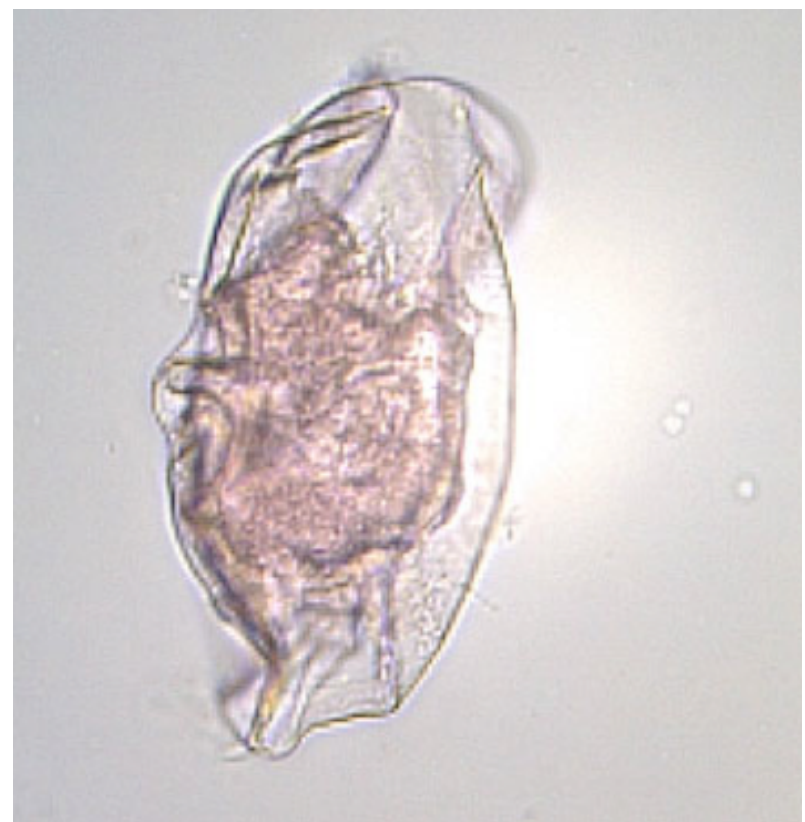

Image 4. Lophocharis salpina (Ehrenberg), lateral view

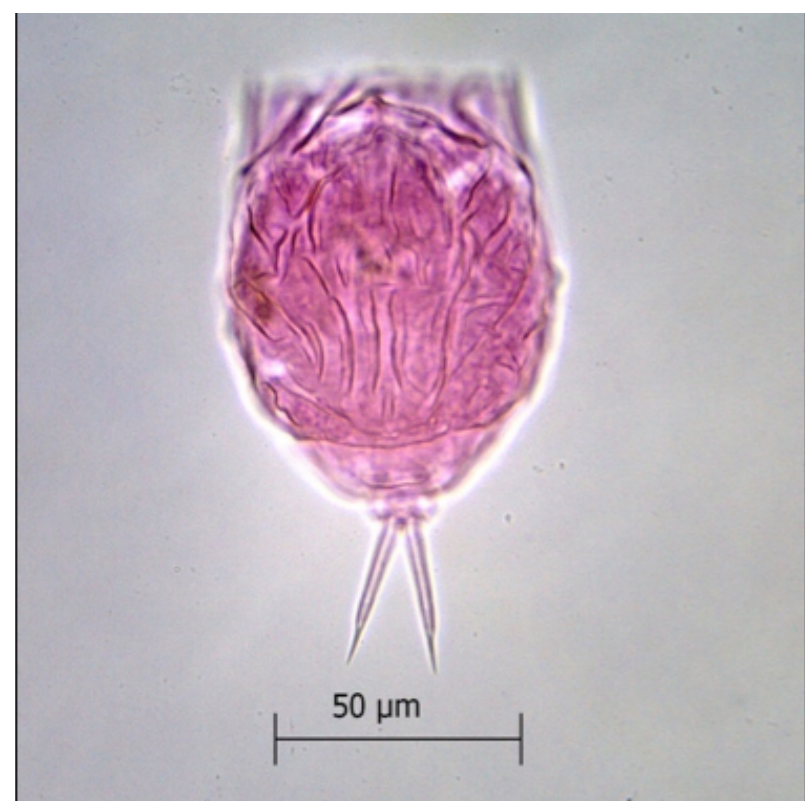

Image 6. Lecane haliclysta Harring \& Myers, dorsal view

in the collections from the Nokrek Biosphere Reserve. Besides, Brachionus mirabilis (Image 3), Lophocharis salpina (Image 4), Mytilina bisulcata (Image 5), Lecane haliclysta (Image 6), L. furcata (Image 7), L. stenroosi (Image 8), Tripleuchlanis propatula, Testudinella parva (Image 9) and T. emarginula (Image 10) are examples of regional distributional interest. Lecane nitida is presently retained as a distinct species in $L$.

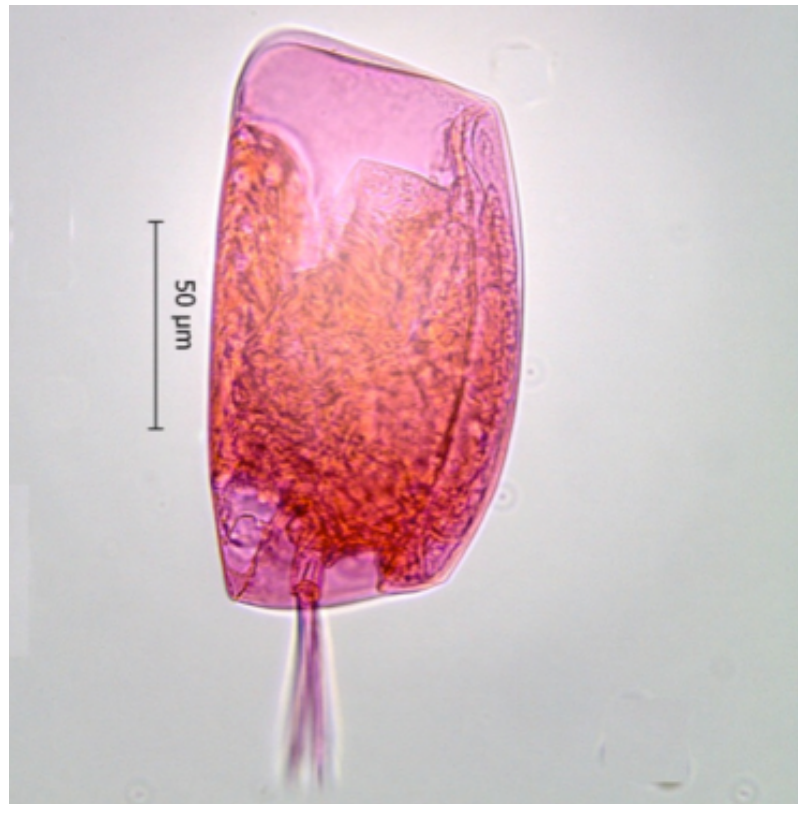

Image 5. Mytilina bisulcata (Lucks), lateral view

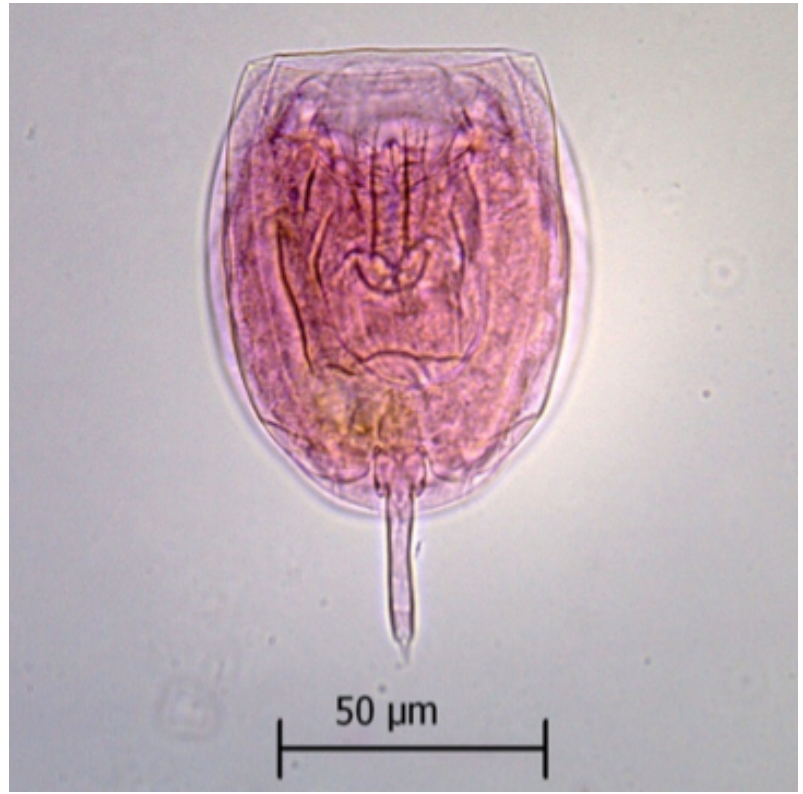

Image 7. Lecane furcata (Murray), ventral view

curvicornis group following Segers \& Sanoamuang (2007).

Lecanidae, one of the largest families ofmonogonont rotifers (Segers 1995), shows a distinct quantitative importance (34.3\%); Brachionidae > Lepadellidae > Notommatidae form notable components (15.7, 10 and $7.1 \%$ respectively) of the rotifer fauna of the Nokrek Biosphere Reserve. Amongst different genera, the 


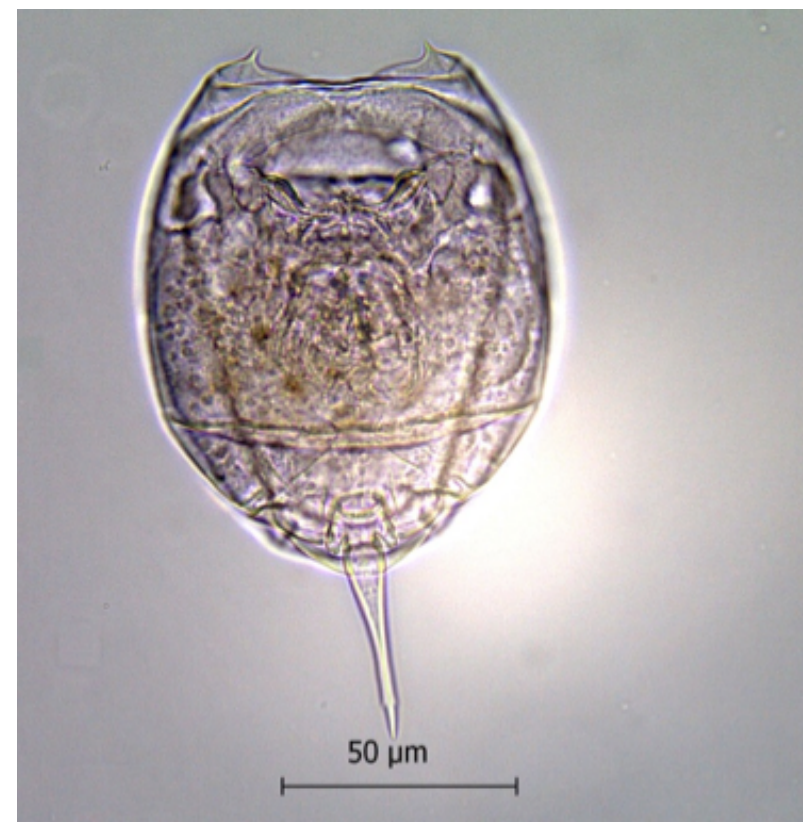

Image 8. Lecane stenroosi (Meissner), dorsal view

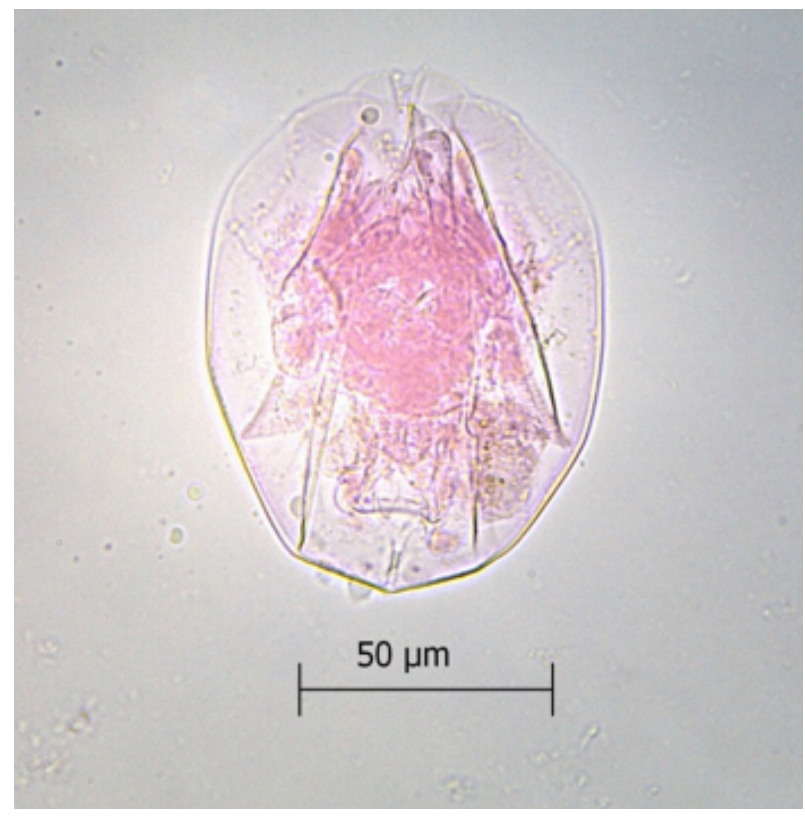

Image 10. Testudinella emarginula (Stenroos), ventral view

'tropic-centered' Lecane shows high richness (24 species) while our collections are characterized by a relative paucity of species of another 'tropic-centered' genus, Brachionus; the latter is attributed to the lack of typical limnetic habitats in the sampled area. Cosmopolitan species (71.2\%) distinctly dominate the rotifer fauna, tropicopolitan species $(16.5 \%)$ are well represented while pantropical $(5.6 \%)$ elements are relatively fewer. In general, the rotifer taxocoenosis

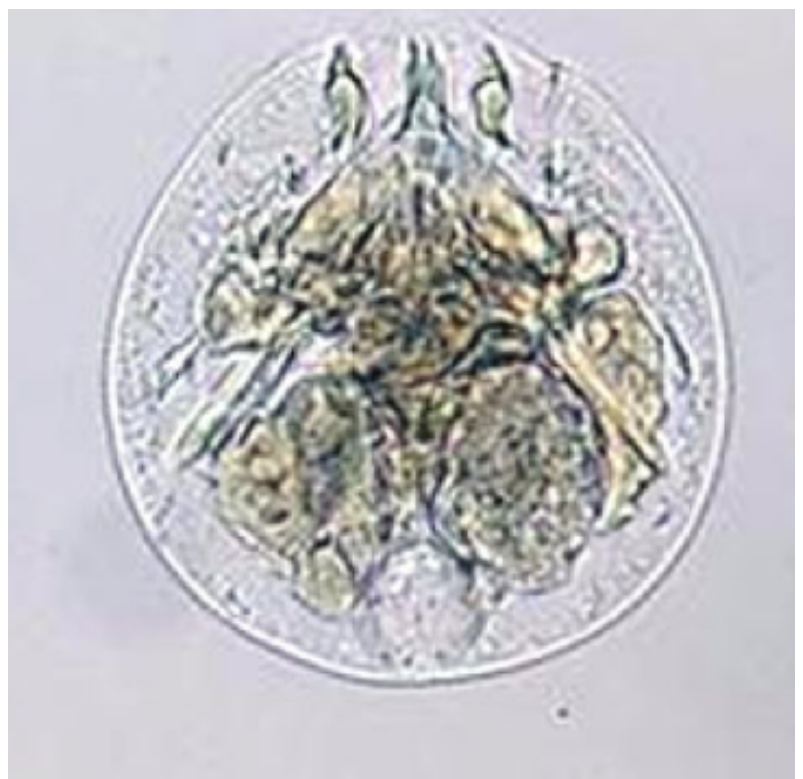

Image 9. Testudinella parva (Ternetz), ventral view

of the Nokrek Biosphere Reserve reflects a 'tropical character'. This generalization is in conformity with identical reports from other tropical faunas (Green 1972; Fernando 1980; Dussart et al. 1984; Segers 1996, 2001, 2008; Sharma 1998a; Sharma \& Sharma 2008). On the other hand, our results differ by lacking the quantitative dominance of Brachionidae, depending on ecological conditions, reported in quite a few of the listed works.

Our collections exhibit interesting variations in Rotifera richness in individual samples (2-23, 11 \pm 5 species). Further, the rotifer communities are characterized by more littoral-periphytonic species and a paucity of planktonic elements. The present study shows the common occurrence of Plationus patulus, Euchlanis dilatata, Lecane bulla, L. leontina, L. luna, L. quadridentata and Testudinella patina while Brachionus bidentatus, B. calyciflorus, B. falcatus, Cephalodella forficula, C. gibba, C. mucronata, Sinantherina socialis, S. spinosa and Testudinella parva are rare species. Monogonont rotifers comprise the bulk of the recorded diversity (67 species) and in turn, show a higher richness of the members of order Ploima while the Bdelloidea include only three species.

To sum up, the Rotifera fauna of the Nokrek Biosphere Reserve reveals 70 species belonging to 24 genera and 15 families including eight new records 
from the state of Meghalaya, It is characterized by the occurrence of certain biographically interesting species, quantitative importance of tropic-centered' Lecane, paucity of Brachionus spp., richness of cosmopolitan species, general 'tropical' character and dominance of littoral-periphytonic species. The present species inventory, however, still requires updating based on more extensive collections as well as specific sampling of benthic and bdelloid rotifers. Nevertheless, this study is an important contribution to aquatic biodiversity of the biosphere reserves or conservation areas of India.

\section{REFERENCES}

Dussart, B.H., C.H. Fernando, J. Matsumura-Tundisi \& R. J. Shiel (1984). A review of systematics, distribution and ecology of tropical freshwater zooplankton. Hydrobiologia 113: 77-91.

Fernando, C.H. (1980). The freshwater zooplankton of Sri Lanka, with a discussion of tropical freshwater zooplankton composition. Internationale Revue Hydrobiologie 65: 411426.

Green, J. (1972). Latitudinal variation in associations of planktonic Rotifera. Journal of Zoology 167: 31-39.

Paggi, S.J. (2001). Diversity of Rotifera (Monogononta) in wetlands of Rio Pilcomayo National Park, Ramsar site (Formosa, Argentina). Hydrobiologia 462: 25-34.

Koste, W. (1978). ROTATORIA. Die Rädertiere Mitteleuropas, begründet von Max Voigt. Überordnung Monogononta. Gebrüder Borntraeger, Berlin, Stuttgart. I. Text U. II. Tafelbd. (T. 234), 673pp.

Patil, S.G. (2001). Rotifera, pp. 25-28. In: Fauna of Nilgiri Biosphere Reserve: Fauna of Conservation Area Series No. 11: Zoological Survey of India, Calcutta.

Sanoamuang, L. (1998). Rotifera of some freshwater habitats in the floodplains of the river Nan, northern Thailand. Hydrobiologia 387/388: 27-33.

Savatenalinton, S. \& H. Segers (2005). Rotifers from Kalasin province, Northeast Thailand, with notes on new and rare species. Zoological Studies 44(3): 361-367.

Seanghun, M. \& L. Sanoamuang (2010). New records of rotifer fauna in the Cambodian Mekong River basin. Cambodian Journal of Natural History 1: 48-62.

Segers, H. (1995). Rotifera 2: Lecanidae. 6: 1-226. In: Dumont, H.J. \& T. Nogrady (eds.) Guides to identification of the Microinvertebrates of the Continental waters of the world. SPB Academic Publishing, Amsterdam, The Netherlands.

Segers, H. (1996). The biogeography of littoral Lecane Rotifera. Hydrobiologia 323:169-197.

Segers, H. (2001). Zoogeography of the Southeast Asian Rotifera. Hydrobiologia 446/447: 233-246.
Segers, H. (2002). The nomenclature of the Rotifera: annotated checklist of valid family- and genus-group names. Journal of Natural History 36: 621-640.

Segers, H. (2008). Global diversity of rotifers (Rotifera) in freshwater. Hydrobiologia 595:49-59.

Segers, H. \& P. Pholpunthin (1997). New and rare Rotifera from Thale Noi Lake, Pattalang Province, Thailand, with a note on the taxonomy of Cephalodella (Notommatidae). Annals of Limnology 33: 13-21.

Segers, H. \& L. Sanoamuang (2007). Note on a highly diverse rotifer assemblage (Rotifera: Monogononta) in a Laotian rice paddy and adjacent pond. Internationale Revue Hydrobiologie 92(6): 240-146.

Segers, H., C.S. Nwadiaro \& H.J. Dumont (1993). Rotifera of some lakes in the floodplain of the River Niger (Imo State, Nigeria) II. Faunal composition and diversity. Hydrobiologia 250: 63-71.

Sharma, B.K. (1998a). Faunal diversity of India: Rotifera, pp. 57-70. In: Alfred, J.R.B., A.K. Das \& A.K. Sanyal (eds.). Faunal Diversity of India. A Commemorative Volume in the 50th Year of India's Independence. ENVIS Centre, Zool. Surv. India, Calcutta

Sharma, B.K. (1998b). Freshwater Rotifers (Rotifera: Eurotatoria), pp. 341-461. In: Fauna of West Bengal. State Fauna Series. Zoological Survey of India, Calcutta.

Sharma, B.K. (2004). Rare and interesting monogonont rotifers (Rotifera, Eurotatoria) from North-Eastern India. Mitteilungen aus dem Museum für Naturkunde Berlin, Zoologische Reihe 80: 33-40.

Sharma, B.K. (2009). Diversity of Rotifers (Rotifera: Eurotatoria) of Loktak lake, North- Eastern India. Tropical Ecology 50(2): 277-285.

Sharma, B.K. \& S. Sharma (1999). Freshwater Rotifers (Rotifera: Eurotatoria), pp. 11-161. In: State Fauna Series: Fauna of Meghalaya. Zoological Survey of India, Calcutta.

Sharma, B.K. \& S. Sharma (2000). Freshwater Rotifers (Rotifera: Eurotatoria), pp. 163-224. In: State Fauna Series: Fauna of Tripura. Zoological Survey of India, Calcutta.

Sharma, B.K. \& S. Sharma (2005a). Biodiversity of freshwater rotifers (Rotifera: Eurotatoria) from North -Eastern India. Mitteilungen aus dem Museum für Naturkunde Berlin, Zoologische Reihe 81: 81-88.

Sharma, B.K. \& S. Sharma (2005b). Faunal diversity of Rotifers (Rotifera: Eurotatoria) of Deepor beel, Assam (N. E. India)- a Ramsar site. Journal of the Bombay Natural History Society 102(2): 169-175.

Sharma, S. (2006). Rotifer diversity (Rotifera : Eurotatoria) of floodplain lakes of Pobitora Wild-Life Sanctuary, Assam. Records of the Zoological Survey of India 106(3): 76-89

Sharma, S. \& B.K. Sharma (2008). Zooplankton diversity in floodplain lakes of Assam. Records of the Zoological Survey of India, Occasional Paper No. 290:1-307.

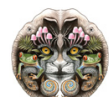

